\title{
The Necessity of Establishing Ecological Compensation Mechanism of Large Hydropower Projects under the Guidance of Government
}

\author{
Guo An \\ School of Economics \\ Sichuan University \\ Chengdu, China
}

\begin{abstract}
Establishment of ecological compensation system under the guidance of government is decided by the socialist nature of China and Chinese basic state. China has abundant natural resources, but the per capita amount is small, and the utilization rate of resources is very low. So, the protection and restoration of natural resources need the guidance of government.
\end{abstract}

Keywords-ecological compensation; mechanism; goverment; large hydropower

I. PROBLEMS OF ECOLOGICAL COMPENSATION OF LARGE HYDROPOWER PROJECTS UNDER THE GUIDANCE OF GOVERNMENT

With the emphasis on the ecological compensation mechanism, the government has a number of conditions as its important guarantee and premise: first, we must establish normative laws and regulations, introduced a series of policies, the formation of the system, the rule of law is the basic policy of our country, the governance of a country, a society, the key is to establish rules, rules, rules, ecological environment legislation is an important measures to promote the implementation of ecological compensation effectively; the two is that the government should have adequate capacity to pay, the use of government public finance to pay ecological products and services, is a kind of ecological compensation model is most widely used in the world, with the development of social economy, ecological compensation costs are increasingly high, the increasingly high demands on the government's ability to pay, so the ecological compensation costs continue to increase under the situation, the government should also have the ability to pay "be inexhaustible"; the three is that the government should have a strong control ability, good coordination between various departments and regions, the interests of the masses the relationship between large hydropower projects, ecological compensation, involving many departments, regions, units and the interests of the residents, in addition to government coordination, it is difficult to find other organizations to coordinate between groups so vast economic interests; the four is the government to eliminate the rentseeking behavior in any form, its dominant role in the process of large-scale ecological compensation in hydropower project right, has a great rent-seeking space, and ecological compensation relates to every stakeholder's interests, if the government rent-seeking behavior, A part of the people to benefit from another part of the loss, will cause great negative impact on ecological compensation; fifth, the government act as an administrator role, and it cannot be in accordance with the rational thinking of the economic people to choose the policy and so on. If the government cannot meet the to these prerequisites, such as in the process of ecological compensation, all levels of government to compensate fund for retention of top-down, which will increase the cost of ecological compensation, increasing pressure on the government to raise funds, and the government in the face of the funding gap and large, make rational economic man choice, would cheat on vulnerable groups, information asymmetry blinded to the engineering development of the compensation to the residents use, resulting in under the guidance of the government, large hydropower project ecological compensation mechanism useless, cannot play have a role. In short, the establishment of large hydropower projects under the guidance of the government, the government's role is very important, the government cannot play its role, will make the ecological compensation mechanism difficult, at present, China's Government in the water and hydropower open ecological compensation experience in the government, the main ecological compensation of large hydropower projects in the following several problems:

\section{A. Financing Channels of a Single and a Large Gap in Funding}

Ecological compensation is an economic means to protect and restore the ecological environment, to coordinate the relationship between the environment and the economic interests of the stakeholders, and promote the common development of the environment and the economy. Since it is a kind of economic means, it is necessary to involve money. For now, the main source of ecological compensation in our country is the government financial transfer payment, including the ecological compensation as the target, the local government financial transfer payment, the local government transfer payments and the horizontal transfer payments between the local governments at the same level. However, the central government transfer payments to local governments, that is, the vertical transfer payments to the absolute dominance, and between the region, between the upstream and downstream of 
the river, the horizontal transfer payments between governments at the same level, which caused the central government's financial pressure is quite large. And tax is the current government fiscal transfer payment is the main source of funding, also said that most of the funds are source to government revenue, at present the taxes on the ecological environment in our country rarely, and linked with the ecological compensation tax only transfer tax, enterprise the acts of tax and tax, although the tax on Chinese ecological compensation made a great contribution, but funding sources and financing amount of income is still not enough to support, it is difficult to guarantee the continuous investment in ecological construction fund.

\section{B. The Government in the Process of Compensation for Color and Public Participation Is Low}

The formulation and implementation of ecological compensation policy is difficult to truly reflect the interests of the relevant stakeholders. The development of large-scale hydropower project is mostly inter basin and inter provincial domain and the particularity of Chinese human geography, resulting in regional development many also involves between different ethnic groups, due to the differences in the various regions and nationalities, the more aggravated the complexity of ecological compensation, and the Chinese government as the ecological compensation policy makers, in the policy formulation process, over emphasized the government's dominant position, on the ecological compensation no conditions, without fully considering the differences between the ethnic minority areas,, to engage across the board, divorced from reality. For example, each province of the ecological compensation standards have different requirements and focus, if you engage in one size fits all, will make a part of the region's people feel their interests have not been fully reflected. Therefore, the policy of ecological compensation has not been the public opinion and suggestion, policy formulation is reflected by the will of the majority of policy makers will.

\section{Lack of Long-Term Effective Ecological Compensation Policy and Legal Basis Is Weak}

Since the founding of new China, our country has set up a series of laws and regulations to protect the ecological environment, however, the foundation of laws and regulations on ecological compensation is relatively weak, it is not perfect. The first is about the rights and obligations of the various stakeholders of ecological compensation, and the contents, methods and standards are not clear, the ecological compensation is a kind of rights, obligations and responsibilities of the stakeholders. Next to the ecological protection and construction of the development of social economy, the contradiction between economic development and ecological environment protection and restoration of ecological environment protection and ecological environment protection and restoration, new problems and new contradictions are emerging, but the long-term and complexity of the law and regulations to determine the pace of legislation is far from the actual situation of the rhythm. Then some important laws and regulations on the ecological protection and compensation standards are not in place. The final regulations of the mandatory requirements of some soft policy to adjust to local conditions.

\section{THE NECESSITY OF ESTABLISHING ECOLOGICAL} COMPENSATION MECHANISM OF HYDROPOWER DEVELOPMENT UNDER THE GOVERNMENT LEAD

\section{A. Need to Maintain National Ecological Security}

Ecological security is a new concept proposed in recent years. In 1989, the international application system analysis and Research Institute (IASA) proposed the concept of "ecological security" for the first time, that is, people's life, health, security, basic rights, life support, the necessary resources, social order and the ability to adapt to environmental changes, etc.. It includes natural, economic and social security of the composite artificial ecosystem. In China, the study on the ecological security of the rise in the last century 90's, but so far, the domestic academic community has not put forward a unified concept of "ecological security. The academic community on the ecological security of the discussion and concern in the ascendant, and the Chinese government is also special attention to ecological security, in April 15, 2014, the Central National Security Council held its first meeting, a clear ecological security into the national security system, ecological security has become an important part of national security. And its concrete performance mainly has several aspects:

1) Ecological security is related to the survival and development of the Chinese nation

The history of the development of human society, in fact, is the history of the change of the ecological environment from a certain point of view. In the long history of the evolution of human development, there have been many dazzling civilization has disappeared, the destruction of such as the Loulan civilization, ancient Egyptian Nile civilization, ancient Babylonian Mesopotamia civilization, ancient Greek civilization, the renowned in the world of civilization, with the ecological environment damage related to serious, lead to the birthplace of civilization resources not to be able to support the survival and development of human beings. The Chinese nation stand among the nations of the world forest up to 5000 years old, although China since ancient times, whether it is individual or the government of the ecological environment very attention, In recent decades, China's rapid development of economy, the demand for various resources is far greater than other development period, the destruction of the ecological environment is greater than the protection of the ecological environment, the inevitable result of some of the ecological environment deterioration: Land Resources degradation, soil erosion, biological resources are constantly destroyed, wild animals and plants and aquatic resources are increasingly depleted, water shortage, mineral resources, forest resources and grassland resources, environmental pollution, etc.. The deterioration of the ecological environment will result in the serious reduction of the resource bottleneck and the environmental capacity, which will affect the development of the economy, but also threaten the survival and development of the Chinese nation.

2) Ecological security is related to national security. 
It is the most basic and most important duty of every government to safeguard the country's living security and development. It takes a long time to show the ecological security, so this will lead to the neglect of ecological security, but once the ecological security has been destroyed, it has been destroyed for a long time, more damage, more difficult to make up. Ecological security and defense, political and economic security, and is not isolated, it is closely linked with people's daily life, such as Beijing's dust storms, the explosion of the PM2.5, the decline in drinking water quality and so on, these are the manifestation of ecological security, national security and public health constitutes a huge threat. Without the ecological security, the basic conditions for human existence will be threatened and destroyed, military, political and economic security will be impossible to talk about.

\section{3) Ecological security is related to the vital interests of the} people.

Ecological security emphasizes people-oriented. For a long time, we recognize the importance of ecological security is obviously inadequate, insufficient system, too much debt. Although this concept also appears in some government documents from time to time, but a lot of people do not really understand the connotation and extension of ecological security. Ecological security cannot be guaranteed, then the people's health, quality of life will not be guaranteed: water pollution, drinking water will become toxic water; air pollution, a variety of respiratory diseases will increase; forest resources are reduced, there will be people living in the sand storm and so on. Another example of hydropower development, since the founding of new China, we in the rivers of the country's seven major river basin, built more than 80000 dams, the dam to protect the our daily life and production of electricity, but the drying up of the Yellow River, the interruption of the Liaohe, Haihe River drying up, Tarim River also flow, seven major river basin there has been basically different degree of drying up, this to people's production and life brought unprecedented difficulties, not only the production of water shortage, even living water can be guaranteed. In 1997 and cutoff of the Yellow River the 226 days, plus year drought, dry season basically did not rain, causing local residents drinking water is very difficult, the individual villagers to walk to 100 much inside and outside water. As a consequence of the reasons leading to in addition to these regions are arid and semi-arid continental climate zone, with dam too much, water diversion and excessive great relationship.

\section{B. To Make up for the Need of Market Failure in Ecological Compensation}

From an economic point of view, ecological compensation refers to the compensation for the ecological environment function and benefit. Hydropower development involves the area in fact is the river basin, in the process of hydropower development, will inevitably cause damage to the ecological environment of the river basin, the destruction of the ecological environment has the external non economic: hydropower companies to intercept the river to build large dams, which will cause damage to other economic entities, and hydropower companies do not make up for the loss of these economic entities or completely compensate, so that the phenomenon of market failure. For example, the construction of hydropower enterprises will flood the woodland grassland, causing the local climate change, but the hydropower companies did not compensate for this behavior.

Ecological compensation if fully rely on the market to adjust, the first need to define the subject and object of the market. In hydropower development ecological compensation, compensation is not clear, and hydropower is clean energy, its production of greenhouse gas emissions and environmental pollution has a certain effect, will bring a certain positive environmental benefits, ecological compensation that is, compensation, compensation is not sure, is the country still benefit people, who can get the ecological services? The compensation for damage to the ecological environment in the process of hydropower development is the main body, which is the main body, which is not clear, cannot fully rely on the market is not feasible, which requires the country to develop ecological compensation of the ecological compensation, and to make the development of the ecological compensation of ecological compensation ". On the one hand is to reduce the water and electricity development enterprises in the ecological environment has no fear of the destruction, eliminate unreasonable development and utilization of environmental pollution and other external causes of the allocation of resources, the other hand, the development of enterprises to improve the enthusiasm of cleaner production, and promote the ecological system of ecological function and value of the restoration.

\section{Need to Raise Funds for Ecological Compensation}

In the process of ecological compensation for large hydropower projects, the problem of financing is the main obstacle. The development of large hydropower projects is a huge impact on the ecological environment, not only the intensity of the impact of a wide range of types, so large hydropower development ecological compensation is needed to raise the amount of money is huge, which completely rely on the market to solve the funding problem is not realistic, and this time, only the government has the ability to bear. First, in our country, the development of large-scale hydropower projects is not just the market behavior, but more reflected in the national development, is the national development, is a national authority, such as the Yangtze River Three Gorges, the construction of the Three Gorges, the State Council approved the establishment of China Three Gorges Project Corp, the entire project is completed, the entire process is reflected in the national will, the need to raise the government. While the national planning and construction of hydropower projects, the other side is the social wealth, that is also the ecological environment of public products, so this requires the national government to carry out unified coordination, to ensure the smooth development of hydropower projects, and can ensure the smooth development of hydropower projects, but also to protect the smooth development of hydropower projects, and can reduce the cost of the project, and finally, the government involved in ecological compensation can reduce transaction costs, and finally, the government involved in ecological compensation can reduce transaction costs, large hydropower development projects involved. Large The development of the 
type of water and electricity is a national development project, the development cost is provided by the state to reduce the cost of the transaction is to reduce the development costs, and to provide the country with the ecological compensation.

\section{The Need to Reflect the National Public Service Functions}

Public service function is the core function of service oriented government, that is, the government directly or indirectly to provide pure public goods and quasi public goods to meet the needs of the community and the public. Ecological environment and its own ecological services have public goods attributes, that is not to send him and non competition, and in our country, the use of ecological environment resources, mostly free or cost is very small, which will lead to the excessive consumption of ecological environment and the use of, and even cause damage, which makes the supply shortage and affect other users. The government has the function of public service, it is required to provide a good and comfortable environment for the masses, while the current hydropower projects have destroyed the ecological environment of the river basin, and lack of effective ecological compensation mechanism. To this end, the establishment of ecological compensation mechanism for hydropower development, the establishment and improvement of ecological environment protection laws and policies, the ecological damage and environmental pollution losses into the national economic accounting system, increase the government's public financial investment, to provide more public products and services to the community, to create a public service government, and strengthen the government's public service functions.

\section{CONCLUSION}

As a new type of resource and environment management model, ecological compensation system is an important way to solve the imbalance between ecological environment and economic development, and the establishment of ecological compensation system is an important part of China's ecological civilization construction. Ecological environment benefit belongs to public interest, but government is the representative of public interest, therefore, the ecological compensation system in our country needs to be dominated by the government.

\section{A. Increase the Input of Ecological Compensation, Strengthen the Research on the Theory of Ecological Compensation, and Strive for a Breakthrough in Theory}

Strengthen the relevant research on the theory of ecological compensation, in particular, to strengthen the study of the number of ecological profit and loss, to lay a solid foundation for the smooth development of ecological compensation. In hydropower development, the research on the profit and loss compensation and compensation standard of water and electricity development of the river basin should be strengthened.

\section{B. The Establishment of Efficient, Unified, Authoritative Management System}

Existing environmental management system, there are many problems, it is difficult to achieve the goal of ecological compensation. Plans, economic and trade, finance, water conservancy and other departments, often from the interests of its departments, the production of heavy economic development, light environmental protection, the idea of environmental protection funds. Therefore, the environmental protection agency as the main ecological compensation management departments, coordination, unified management of other departments state compensation, and the compensation fees charged are by the finance and taxation departments under a unified to, be in the collection work and compensation procedure standardization, systematization.

\section{Increase the Publicity Efforts of Ecological Compensation}

To strengthen the propaganda and popularization of the knowledge of ecological compensation, so as to make a household name, to accept and recognize the public, and to provide public opinion support and social security for the establishment of ecological compensation system for hydropower development.

\section{The Construction of Environmental Law in China, The Main Body and The Principle of Ecological Compensation}

Including the principle of ecological justice, common development principle, and who benefits who do not compensate for the principle. Ecological justice principle, the more serious damage to the ecological environment, in the economy is relatively backward areas, construction of ecological civilization, should be based on the premise of fair development, the principle of common development, is not only to the ecological environment and economic development, but also in the region to achieve common development.

\section{REFERENCES}

[1] Stefano Pagiola, Jushua Bishop,Natasha,Landell-mills,et al. Selling forest environmental services: market-based mechanisms for conservation and development, Cambridge: MIT Press, 2002: 24-28

[2] Natasha Landell Porras. Silver bullet or fools' gold?-Aglobal review of markets for forest environmental services and the impact on the poor. 2002-09-23

[3] OECD. Improving the environmental performance of agriculture. Policy options and Market approaches, 2001,23-26

[4] Jones Charles. Macroeconomics. Cambridge: MIT Press, 1994,(6):22

[5] Lawrence M.Frideman. Legal Culture and Social Developing, New York: Law and Social Review, 1999,24-26 